\title{
FAKTOR-FAKTOR YANG BERHUBUNGAN DENGAN PERILAKU MEROKOK DI MTS NEGERI O1 KOTA LUBUKLINGGAU
}

\author{
Santoso Ujang Effendi ${ }^{1}$, Susilo Wulan ${ }^{2}$, Fitratul Wahyuni ${ }^{3}$ \\ Program Studi S1 Kesehatan Masyarakat \\ STIKES Tri Mandiri Sakti Bengkulu \\ santos_ue@yahoo.com ${ }^{1}$,wulan.susilo@gmail.com²
}

\begin{abstract}
Health development is starting to face a new pattern of disease, which is an increase in cases of noncommunicable diseases triggered by changes in people's lifestyles including cigarette consumption, whose prevalence continues to increase. This study aimed to study the factors associated with smoking behavior in students in MTS Negeri 01 Lubuklinggau City. This type of study was Analytic Survey and Cross Sectional study design. The population of this study was all male students of VII and VIII class in MTS Negeri 01 Lubuklinggau City in the 2018/2019 school year totaling 333 students. The sampling technique in this study used Proportional Random Sampling to obtain a sample of 77 students. The analysis in this study used univariate analysis and bivariate analysis. Bivariate analysis used Chi-Square test ( $\chi 2)$. To determine closeness of relationship used Contingency Coefficient $(C)$ test. The results showed that of 77 students, there were 33 students (42.9\%) who lacked knowledge, 45 students (58.4\%) who were supportive of smoking behavior, 43 students (55.8\%) who had their peers who supported smoking, and 46 students (59.7\%) who behaved smoking. The results of bivariate analysis showed that there was a significant relationship between students' knowledge, students's attitudes, and students's peers with smoking behavior of students in MTS Negeri 01, Lubuklinggau City with a moderate relationship category.
\end{abstract}

Keywords: Attitude, Knowledge, Peers, Smoking Behavior, Student

\begin{abstract}
ABSTRAK
Pembangunan kesehatan mulai menghadapi pola penyakit baru, yaitu meningkatnya kasus penyakit tidak menular yang dipicu berubahnya gaya hidup masyarakat di antaranya adalah konsumsi rokok yang prevalensinya terus meningkat. Penelitian ini bertujuan mempelajari faktor-faktor yang berhubungan dengan perilaku merokok pada siswa di MTS Negeri 01 Kota Lubuklinggau. Jenis penelitian ini adalah Survey Analitik dan desain penelitian Cross Sectional. Populasi dalam penelitian ini adalah seluruh siswa laki-laki kelas VII dan VIII di MTS Negeri 01 Kota Lubuklinggau tahun ajaran 2018/2019 yang berjumlah sebanyak 333 orang siswa. Teknik pengambilan sampel pada penelitian ini menggunakan Proportional Random Sampling sehingga diperoleh sampel sebesar 77 orang siswa. Analisis dalam penelitian ini menggunakan analisis univariat dan analisis bivariat. Analisis bivariat menggunakan uji Chi-Square $\left(\chi^{2}\right)$. Untuk mengetahui keeratan hubungan menggunakan uji Contingency Coefficient (C). Hasil penelitian menunjukkan bahwa dari 77 orang siswa, terdapat 33 orang siswa $(42,9 \%)$ yang berpengetahuan kurang, 45 orang siswa $(58,4 \%)$ yang bersikap mendukung perilaku merokok, 43 orang siswa $(55,8 \%)$ yang memiliki teman sebaya yang mendukung perilaku merokok, dan 46 orang siswa (59,7\%) yang memiliki perilaku merokok. Hasil analisis bivariat menunjukkan bahwa ada hubungan yang signifikan antara pengetahuan siswa, sikap siswa dan teman sebaya dengan perilaku merokok pada siswa di MTS Negeri 01 Kota Lubuklinggau dengan kategori hubungan sedang.
\end{abstract}

Kata Kunci : Pengetahuan, Perilaku Merokok, Sikap, Siswa, Teman Sebaya

PENDAHULUAN

Pembangunan kesehatan mulai menghadapi pola penyakit baru, yaitu meningkatnya kasus penyakit tidak menular yang dipicu berubahnya gaya hidup masyarakat seperti pola makan rendah serat dan tinggi lemak serta konsumsi garam dan 
gula berlebih, kurang aktifitas fisik (olah raga) dan konsumsi rokok yang prevalensinya terus meningkat (Pangestu, Cahyo, dan Kusumawati, 2017).

Menurut World Health Organization (WHO) dan hasil studi lainnya, terdapat sekitar satu miliar perokok di dunia atau sekitar sepertujuh dari populasi global. Cina menempati angka tertinggi. Dari penduduknya sebesar 1,3 miliar, sekitar 315 jutanya adalah perokok dan mereka mengonsumsi lebih dari sepertiga dari rokok dunia. Namun jika dilihat dari persentase penduduk, Indonesia menempati persentase penduduk sebagai perokok terbesar di dunia. Ada $76,0 \%$ pria berusia di atas 15 tahun tercatat sebagai perokok. Sekitar 80,0\% perokok dunia hidup di negara berpenghasilan rendah dan menengah dan 226 juta di antaranya dianggap miskin (Kemenkes RI, 2018).

Dari data Riskesdas tahun 2013, Perilaku merokok penduduk remaja umur 15 tahun ke atas masih belum terjadi penurunan dari tahun 2007 ke tahun 2013, cenderung meningkat dari 34,2\% tahun 2007 menjadi $36,3 \%$ tahun 2013. Ada 64,9\% laki-laki dan $2,1 \%$ perempuan masih menghisap rokok tahun 2013. Ada 1,4\% perokok umur 10-14 tahun, 9,9\% perokok pada kelompok tidak bekerja, dan 32,3\% pada kelompok kuintil indeks kepemilikan terendah. Rerata jumlah batang rokok yang dihisap adalah sekitar 12,3 batang, bervariasi dari yang terendah 10 batang di DI Yogyakarta dan tertinggi di Bangka Belitung (18,3 batang) (Kemenkes RI, 2013).

Dari data Riskesdas tahun 2013 rerata batang rokok yang dihisap perhari penduduk remaja umur $\geq 10$ tahun di Indonesia adalah 12,3 batang (setara satu bungkus). Jumlah rerata batang rokok terbanyak yang dihisap ditemukan di Bangka Belitung (18 batang). Proporsi terbanyak perokok aktif setiap hari pada umur 30-34 tahun sebesar 33,4\%. Pada perokok laki-laki lebih banyak jika dibandingkan dengan perokok perempuan (47,5\% banding $1,1 \%)$. Berdasarkan jenis pekerjaan, petani/nelayan/buruh adalah perokok aktif yang mempunyai proporsi terbesar (44,5\%) jika dibandingkan kelompok pekerjaan lainnya. Proporsi perokok setiap hari tampak cenderung menurun pada kuintil indeks kepemilikan yang lebih tinggi (Kemenkes RI, 2013).

Merebaknya perilaku merokok pada remaja dapat dilihat dari kajian perkembangan remaja. Erikson dalam Komasari dan Helmi (2000) menyatakan bahwa perilaku merokok pada remaja terkait dengan proses krisis aspek psikososial, yaitu masa ketika mereka tengah berusaha mencari jati dirinya (masa badai dan topan). Selama tahun-tahun awal remaja, individu mengalami masalah utama biologis, kognitif, perubahan sosial, dan emosional yang mempengaruhi pilihan perilaku, termasuk bereksperimen dengan perilaku yang tidak sehat, misalnya merokok. Risiko kesehatan awal, inisiasi merokok yang parah, dan pola perilaku tidak sehat pada remaja sering meluas terbawa sampai dewasa.

Perilaku merokok pada remaja merupakan bentuk kompensasi. Sesuai dengan yang dikemukakan oleh Komasari dan Helmi (2000) bahwa perilaku merokok bagi remaja merupakan bentuk perilaku simbolisasi. Simbol dari kematangan, kedewasaan, kekuatan, kepemimpinan, dan daya tarik terhadap teman lawan jenisnya.

Berdasarkan hasil penelitian Pangestu, Cahyo, dan Kusumawati (2017), faktorfaktor yang berhubungan dengan perilaku merokok Shisha pada Siswa SMA X di Kota Semarang adalah pengetahuan, sikap, teman sebaya dan ketersediaan sumber daya. Hasil penelitian yang dilakukan oleh Suprayitno (2013) pada siswa di SMK Sepuluh November Semarang menunjukkan bahwa terdapat pengaruh yang positif dari kelompok teman sebaya terhadap terjadinya perilaku merokok remaja secara signifikan.

Di Sumatera Selatan tingkat pertumbuhan jumlah perokok melebihi tingkat pertumbuhan penduduk karena kebijakan cukai rokok belum efektif untuk mengendalikan konsumsi rokok, dengan permintaan masih relatif tinggi sehingga memicu produksi terus meningkat. Berdasarkan data dari Riskesdas dalam 
angka Provinsi Sumatera Selatan tahun 2013, berdasarkan proporsi penduduk menurut umur kebiasaan merokok pada kelompok umur 10-14 tahun, perokok setiap hari sebesar $0,5 \%$ dan perokok kadang-kadang sebesar 1,0\%. Pada kelompok umur 15-19 tahun, perokok setiap hari sebesar 10,9\% dan perokok kadang-kadang sebesar 8,4\%. Kelompok yang tertinggi ada pada kelompok umur 30-34 tahun, dengan jumlah perokok setiap hari sebesar $35,4 \%$ dan perokok kadang-kadang sebesar 5,9\%. Sementara itu di Kota Lubuklinggau jumlah perokok berdasarkan proporsi penduduk umur $\geq 10$ tahun pada tahun 2013, jumlah perokok setiap hari sebesar $25,1 \%$ dan perokok kadang-kadang sebanyak 4,0\% (Kemenkes RI, 2013).

Berdasarkan survei awal yang dilakukan peneliti, dari 17 orang siswa yang diwawancara, terdapat 13 orang siswa yang mengaku pernah merokok dan 4 orang siswa mengaku tidak pernah merokok. Ada 4 orang siswa mengaku merokok disebabkan karena kurang memahami tentang bahaya ataupun dampak yang ditimbulkan jika merokok, dan 4 orang siswa yang diwawancarai mengaku merokok karena merasa percaya diri jika merokok dan merasa mulutnya bau jika tidak merokok.

Ada 5 siswa yang mengaku merokok, mengatakan bahwa mereka merokok karena diajak teman. Merokok untuk pergaulan bersama teman karena dengan merokok bersama, merasa pertemanan lebih solid dan bisa menemukan ide-ide baru.

\section{METODE}

Jenis penelitian ini adalah Survey Analitik dan desain penelitian yang digunakan adalah Cross sectional. Penelitian ini telah dilaksanakan pada tanggal 10-14 Juni 2019 di MTS Negeri 01 Kota Lubuklinggau. Populasi dalam penelitian ini adalah seluruh siswa laki-laki kelas VII dan VIII di MTS Negeri 01 Kota Lubuklinggau tahun ajaran 2018/2019 dan diketahui berjumlah 333 orang siswa. Sampel dalam penelitian ini adalah 77 orang siswa yang diambil dengan menggunakan teknik Proportional Random Sampling. Teknik pengumpulkan data adalah data primer dan data sekunder. Analisis dalam penelitian ini dengan analisis univariat dan analisis bivariat. Analisis bivariat menggunakan uji Chi-Square $\left(\chi^{2}\right)$. Untuk mengetahui keeratan hubungan menggunakan uji Contingency Coefficient (C).

\section{HASIL}

\section{Analisis Univariat}

Analisis univariat bertujuan untuk mendapatkan gambaran pengetahuan siswa, sikap siswa, teman sebaya dan perilaku merokok pada siswa di MTS Negeri 01 Kota Lubuklinggau. Hasil analisis univariat dapat dilihat pada tabel berikut ini:

Tabel 1. Distribusi Frekuensi Pengetahuan Siswa di MTS Negeri 01 Kota Lubuklinggau

\begin{tabular}{|c|c|c|c|}
\hline No. & Pengetahuan Siswa & Frekuensi & Persentase (\%) \\
\hline 1 & Kurang & 33 & 42,8 \\
\hline 2 & Cukup & 26 & 33,8 \\
\hline \multirow[t]{2}{*}{3} & Baik & 18 & 23,4 \\
\hline & Total & 77 & 100,0 \\
\hline
\end{tabular}

Keterangan : Data Primer, 2019

Berdasarkan Tabel 1 diketahui dari 77 orang siswa di MTS Negeri 01 Kota Lubuklinggau, terdapat 33 orang siswa $(42,8 \%)$ yang berpengetahuan kurang, 26 orang siswa $(33,8 \%)$ yang berpengetahuan cukup dan 18 orang siswa $(23,4 \%)$ yang berpengetahuan baik. 
Tabel 2. Distribusi Frekuensi Sikap Siswa di MTS Negeri 01 Kota Lubuklinggau

\begin{tabular}{|c|c|c|c|}
\hline No. & Sikap siswa & Frekuensi & Persentase ( \% ) \\
\hline 1 & Mendukung & 45 & 58,4 \\
\hline 2 & Tidak Mendukung & 32 & 41,6 \\
\hline & Total & 77 & 100,0 \\
\hline
\end{tabular}

Keterangan : Data Primer, 2019

Berdasarkan Tabel 2 dapat diketahui bahwa dari 77 orang siswa di MTS Negeri 01 Kota Lubuklinggau, terdapat 45 orang siswa $(58,4 \%)$ yang bersikap mendukung dan 32 orang siswa $(41,6 \%)$ yang bersikap tidak mendukung.

Tabel 3. Distribusi Frekuensi Teman Sebaya di MTS Negeri 01 Kota Lubuklinggau

\begin{tabular}{clcc}
\hline No. & Teman Sebaya & Frekuensi & Persentase ( \%) \\
\hline 1 & Mendukung & 43 & 55,8 \\
2 & Tidak Mendukung & 34 & 44,2 \\
\hline \multicolumn{2}{c}{ Total } & $\mathbf{7 7}$ & $\mathbf{1 0 0 , 0}$
\end{tabular}

Keterangan : Data Primer, 2019

Berdasarkan Tabel 3 dapat diketahui bahwa dari 77 orang siswa di MTS Negeri 01 Kota Lubuklinggau, terdapat 43 orang siswa $(55,8 \%)$ yang memiliki teman sebaya yang mendukung perilaku merokok dan 34 orang siswa $(44,2 \%)$ yang memiliki teman sebaya yang tidak mendukung perilaku merokok.

Tabel 4. Distribusi Frekuensi Perilaku Merokok pada Siswa di MTS Negeri 01 Kota Lubuklinggau

\begin{tabular}{|c|c|c|c|}
\hline No. & Perilaku Merokok & Frekuensi & Persentase (\%) \\
\hline 1 & $\mathrm{Ya}$ & 46 & 59,7 \\
\hline \multirow[t]{2}{*}{2} & Tidak & 31 & 40,3 \\
\hline & Total & 77 & 100,0 \\
\hline
\end{tabular}

Keterangan : Data Primer, 2019

Berdasarkan Tabel 4 dapat diketahui bahwa dari 77 orang siswa di MTS Negeri 01 Kota Lubuklinggau, terdapat 46 orang siswa $(59,7 \%)$ yang memiliki perilaku merokok dan 31 orang siswa $(40,3 \%)$ yang tidak memiliki perilaku merokok.

\section{Analisis Bivariat}

Analisis bivariat bertujuan untuk mengetahui hubungan antara pengetahuan siswa, sikap siswa, dan teman sebaya dengan perilaku merokok pada siswa di MTS Negeri 01 Kota Lubuklinggau. Hasil analisis bivariat dapat dilihat pada tabel berikut ini:

Tabel 5. Hubungan Pengetahuan Siswa dengan Perilaku Merokok pada Siswa di MTS Negeri 01 Kota Lubuklinggau

\begin{tabular}{|c|c|c|c|c|c|c|c|c|c|}
\hline \multirow{3}{*}{ Pengetahuan } & \multicolumn{6}{|c|}{ Perilaku Merokok } & \multirow{3}{*}{$\chi^{2}$} & \multirow{3}{*}{$\mathbf{p}$} & \multirow{3}{*}{$\mathbf{C}$} \\
\hline & \multicolumn{2}{|c|}{$\mathbf{Y a}$} & \multicolumn{2}{|c|}{ Tidak } & \multicolumn{2}{|c|}{ Total } & & & \\
\hline & f & $\%$ & $\mathbf{f}$ & $\%$ & $\mathbf{F}$ & $\%$ & & & \\
\hline Kurang & 26 & 78,8 & 7 & 21,2 & 33 & 100,0 & \multirow{4}{*}{10,004} & \multirow{4}{*}{0,007} & \multirow{4}{*}{0,339} \\
\hline Cukup & 10 & 38,5 & 16 & 61,5 & 26 & 100,0 & & & \\
\hline Baik & 10 & 55,6 & 8 & 44,4 & 18 & 100,0 & & & \\
\hline Total & 46 & 59,7 & 31 & $\mathbf{4 0 , 3}$ & 77 & 100,0 & & & \\
\hline
\end{tabular}

Keterangan : Data Primer, 2019

Berdasarkan Tabel 5 dapat diketahui bahwa dari 33 orang siswa yang pengetahuannya kurang, terdapat 26 orang siswa yang memiliki perilaku merokok dan 7 orang siswa yang tidak memiliki perilaku merokok. Dari 26 orang siswa yang 
pengetahuannya cukup, terdapat 10 orang siswa yang memiliki perilaku merokok dan 16 orang siswa yang tidak memiliki perilaku merokok. Dari 18 orang siswa yang pengetahuannya baik, terdapat 10 orang siswa yang memiliki perilaku merokok dan 8 orang siswa yang tidak memiliki perilaku merokok di MTS Negeri 01 Kota Lubuklinggau.
Hasil uji Pearson Chi-Square didapat sebesar 10,004 dengan nilai asymp.sig $(p)=0,007$. Karena nilai $p<0,05$. Artinya ada hubungan antara pengetahuan siswa dengan perilaku merokok pada siswa di MTS Negeri 01 Kota Lubuklinggau. Hasil uji Contingency Coefficient didapatkan nilai $\mathrm{C}=$ 0,339 . Karena nilai $\mathrm{C}=0,339$ dekat dengan nilai $\mathrm{C} \max =0,707$, maka kategori hubungan sedang.

Tabel 6. Hubungan Sikap Siswa dengan Perilaku Merokok pada Siswa di MTS Negeri 01 Kota Lubuklinggau

\begin{tabular}{|c|c|c|c|c|c|c|c|c|c|}
\hline \multirow{3}{*}{ Sikap } & \multicolumn{6}{|c|}{ Perilaku Merokok } & \multirow{3}{*}{$\chi^{2}$} & \multirow{3}{*}{$\mathbf{p}$} & \multirow{3}{*}{$\mathbf{C}$} \\
\hline & \multicolumn{2}{|c|}{ Ya } & \multicolumn{2}{|c|}{ Tidak } & \multicolumn{2}{|c|}{ Total } & & & \\
\hline & f & $\%$ & f & $\%$ & $\mathbf{F}$ & $\%$ & & & \\
\hline Mendukung & 34 & 75,6 & 11 & 24,4 & 45 & 100,0 & & & \\
\hline Tidak Mendukung & 12 & 37,5 & 20 & 62,5 & 32 & 100,0 & 9,734 & 0,002 & 0,357 \\
\hline Total & 46 & 59,7 & 31 & 40,3 & 77 & 100,0 & & & \\
\hline
\end{tabular}

Keterangan : Data Primer, 2019

Berdasarkan Tabel 6 dapat diketahui bahwa dari 45 orang siswa yang bersikap mendukung, terdapat 34 orang siswa yang memiliki perilaku merokok dan 11 orang siswa yang tidak memiliki perilaku merokok. Dari 32 orang siswa yang bersikap tidak mendukung, terdapat 12 orang siswa yang memiliki perilaku merokok dan 20 orang siswa yang tidak memiliki perilaku merokok di MTS Negeri 01 Kota Lubuklinggau.
Hasil uji Continuity Correction didapat sebesar 9,734 dengan nilai asymp.sig $(\mathrm{p})=0,002$, karena nilai $\mathrm{p}<0,05$. Artinya ada hubungan sikap siswa dengan perilaku merokok pada siswa di MTS Negeri 01 Kota Lubuklinggau. Hasil uji Contingency Coefficient didapat nilai $\mathrm{C}=0,357$. Karena nilai $\mathrm{C}=0,357$ dekat dengan nilai $\mathrm{Cmax}=$ 0,707, maka kategori hubungan sedang.

Tabel 7. Hubungan Teman Sebaya dengan Perilaku Merokok pada Siswa di MTS Negeri 01 Kota Lubuklinggau

\begin{tabular}{|c|c|c|c|c|c|c|c|c|c|}
\hline \multirow{3}{*}{ Teman Sebaya } & \multicolumn{6}{|c|}{ Perilaku Merokok } & \multirow{3}{*}{$\chi^{2}$} & \multirow{3}{*}{$\mathbf{p}$} & \multirow{3}{*}{$\mathbf{C}$} \\
\hline & \multicolumn{2}{|c|}{ Ya } & \multicolumn{2}{|c|}{ Tidak } & \multicolumn{2}{|c|}{ Total } & & & \\
\hline & $\mathrm{f}$ & $\%$ & f & $\%$ & f & $\%$ & & & \\
\hline Mendukung & 35 & 81,4 & 8 & 18,6 & 43 & 100,0 & & & \\
\hline Tidak Mendukung & 11 & 32,4 & 23 & 67,6 & 34 & 100,0 & 17,003 & 0,000 & 0,445 \\
\hline Total & 46 & 59,7 & 31 & 40,3 & 77 & 100,0 & & & \\
\hline
\end{tabular}

Keterangan : Data Primer, 2019

Berdasarkan Tabel 7 dapat diketahui bahwa dari 43 orang siswa yang memiliki teman sebaya yang mendukung perilaku merokok, terdapat 35 orang siswa yang memiliki perilaku merokok dan 8 orang siswa yang tidak memiliki perilaku merokok. Dari 34 orang siswa yang memiliki teman sebaya yang tidak mendukung perilaku merokok, terdapat 11 orang siswa yang memiliki perilaku merokok dan 23 orang siswa yang tidak memiliki perilaku merokok di MTS Negeri 01 Kota Lubuklinggau.

Hasil uji Continuity Correction didapat sebesar 17,003 dengan nilai asymp.sig $(p)=0,000$. Karena nilai $p<0,05$. Artinya ada hubungan teman sebaya dengan perilaku merokok pada siswa di MTS Negeri 01 Kota Lubuklinggau. Hasil uji contingency coefficient didapat nilai $\mathrm{C}=0,445$. Karena nilai $\mathrm{C}=0,445$ dekat dengan nilai $\mathrm{Cmax}=$ 0,707, maka kategori hubungan sedang. 


\section{PEMBAHASAN}

\section{Hubungan Pengetahuan Siswa dengan Perilaku Merokok}

Berdasarkan hasil analisis bivariat, dari 33 orang siswa yang berpengetahuan kurang, terdapat 7 orang siswa yang tidak memiliki perilaku merokok. Hal ini dikarenakan mereka mengatakan takut melihat gambar peringatan tentang bahaya rokok yang terdapat di bungkus rokok dan uang belanja sekolah sehari-hari tidak cukup untuk membeli rokok. Dari 26 orang siswa yang berpengetahuan cukup, terdapat 16 orang siswa yang tidak berperilaku merokok. Hal ini dikarenakan mereka sudah mengetahui bahaya dan penyakit yang diakibatkan oleh rokok, zat yang terkandung dalam rokok, dan dampak rokok bagi kesehatan. Dari 18 orang siswa yang pengetahuannya baik, terdapat 10 orang siswa yang berperilaku merokok. Hal ini karenakan mereka terpengaruh oleh pergaulan dan menjadi kecanduan untuk merokok.

Hasil uji statistik Chi-Square menunjukkan bahwa ada hubungan yang signifikan antara pengetahuan siswa dengan perilaku merokok pada siswa di MTS Negeri 01 Kota Lubuklinggau. Artinya adalah pengetahuan siswa menentukan perilaku merokok pada siswa di MTS Negeri 01 Kota Lubuklinggau

Hasil penelitian ini sejalan dengan hasil penelitian Maseda, Suba, dan Wongkar (2013) yang menunjukkan bahwa ada hubungan antara pengetahuan remaja dengan perilaku merokok pada remaja putra di SMA Negeri I Tompasobaru. Hasil penelitian ini juga sejalan dengan hasil penelitian Kurniasih (2008) pada siswa SLTP di Kota Bekasi yang menunjukkan bahwa ada hubungan antara pengetahuan antara tingkat pengetahuan dengan kebiasaan merokok.

Menurut Wahyuni (2010), sebelum seseorang mengadopsi perilaku di dalam diri orang tersebut terjadi proses yang berurutan yaitu kesadaran, merasa tertarik, menimbang-nimbang, mencoba, dan adopsi. Seseorang telah berperilaku baru sesuai dengan pengetahuan, kesadaran, dan sikapnya terhadap stimulus.

Hasil penelitian ini sesuai dengan teori yang dikemukakan oleh Notoatmodjo (2014) yang menyatakan bahwa pengetahuan merupakan faktor dominan yang paling penting untuk terbentuknya tindakan seseorang (overt behavior) dan pengetahuan dapat diukur dengan melakukan wawancara. Perilaku yang didasari dengan pengetahuan dan kesadaran akan lebih bertahan lama dari pada perilaku yang tidak didasari ilmu pengetahuan dan kesadaran.

\section{Hubungan Sikap Siswa dengan Perilaku Merokok}

Berdasarkan hasil analisis bivariat, dari 45 orang siswa yang bersikap mendukung perilaku merokok, terdapat 11 orang siswa yang tidak memiliki perilaku merokok. Hal ini dikarenakan mereka tahu kalau merokok dapat menyebabkan penyakit jantung, kanker paru, kanker mulut, TBC, dan pengeroposan tulang. Dari 32 orang siswa yang tidak mendukung perilaku merokok, terdapat 12 orang siswa yang merokok. Hal ini dikarenakan mereka akan dijauhi oleh teman-temannya jika tidak merokok dan harga rokok juga terjangkau dengan mereka.

Hasil uji statistik Chi-Square menunjukkan bahwa ada hubungan yang signifikan antara sikap siswa dengan perilaku merokok pada siswa di MTS Negeri 01 Kota Lubuklinggau. Artinya adalah sikap siswa menentukan perilaku merokok pada siswa di MTS Negeri 01 Kota Lubuklinggau.

Hasil penelitian sejalan dengan penelitian yang dilakukan oleh Pangestu, Cahyo, dan Kusumawati (2017) yang menunjukkan bahwa sikap berhubungan dengan perilaku merokok Shisha pada Siswa SMA X di Kota Semarang. Hasil penelitian ini juga sejalan dengan hasil penelitian Maseda, Suba, dan Wongkar (2013) yang menunjukkan bahwa ada hubungan antara sikap remaja dengan perilaku merokok pada remaja putra di SMA Negeri I Tompasobaru. 
Hasil penelitian ini sesuai dengan teori yang menyatakan bahwa sikap adalah respon tertutup seseorang terhadap stimulus atau objek tertentu, yang sudah melibatkan faktor-faktor pendapat dan emosi yang bersangkutan. Newcomb, salah seorang ahli psikologi sosial menyatakan, bahwa sikap merupakan kesiapan atau kesediaan untuk bertindak, dan bukan merupakan pelaksanaan motif tertentu. Dalam kata lain, fungsi sikap belum merupakan tindakan (reaksi terbuka) atau aktivitas, akan tetapi merupakan predisposisi perilaku (tindakan) atau reaksi (Notoatmodjo, 2010).

\section{Hubungan Teman Sebaya dengan Perilaku Merokok}

Berdasarkan hasil analisis bivariat, dari 43 orang siswa yang memiliki teman sebaya yang mendukung perilaku merokok, terdapat 8 orang siswa yang tidak merokok. Hal ini dikarenakan mereka tidak terpengaruh walaupun diajak teman mereka untuk merokok dan mereka akan menolak jika ada teman yang mengajak mereka merokok. Dari 34 orang siswa yang memiliki teman sebaya yang tidak mendukung perilaku merokok, terdapat 11 orang siswa yang merokok. Hal ini dikarenakan mereka merasa akan lebih diperhatikan oleh temannya jika mereka merokok dan merasa nyaman ketika merokok bersama temantemannya.

Hasil uji statistik Chi-Square menunjukkan bahwa ada hubungan yang signifikan antara teman sebaya dengan perilaku merokok pada siswa di MTS Negeri 01 Kota Lubuklinggau. Artinya adalah teman sebaya menentukan perilaku merokok pada siswa di MTS Negeri 01 Kota Lubuklinggau.

Hasil penelitian ini sejalan dengan penelitian yang dilakukan oleh Suprayitno (2013) pada remaja di SMK Sepuluh November Semarang yang menunjukkan bahwa terdapat pengaruh yang positif dari kelompok teman sebaya terhadap terjadinya perilaku merokok remaja secara signifikan. Penelitian ini juga sejalan dengan penelitian yang dilakukan oleh Hasanah dan Sulastri
(2011) pada siswa laki-laki Madrasah Aliyah Negeri 2 Boyolali yang menunjukkan bahwa terdapat hubungan yang signifikan antara dukungan teman sebaya dengan perilaku merokok dengan kategori hubungan kuat.

Hasil penelitian ini sesuai dengan teori Santrock (2003) yang mengemukakan bahwa tekanan untuk mengikuti teman sebaya menjadi sangat kuat pada saat masa remaja. Artinya tekanan sosial dari teman sebaya tidak hanya berupa tekanan nyata tetapi juga ada tekanan yang dibayangkan oleh mereka, sehingga dapat mengubah perilaku mereka untuk mengikuti apa yang dilakukan oleh teman sebaya.

\section{KESIMPULAN}

Berdasarkan hasil penelitian tentang "Hubungan antara Pengetahuan Siswa, Sikap Siswa, dan Teman Sebaya dengan Perilaku Merokok pada Siswa di MTS Negeri 01 Kota Lubuklinggau dapat disimpulkan bahwa :

1. Dari 77 orang siswa di MTS Negeri 01 Kota Lubuklinggau, terdapat 33 orang siswa $(42,8 \%)$ yang berpengetahuan kurang.

2. Dari 77 orang siswa di MTS Negeri 01 Kota Lubuklinggau, terdapat 45 orang siswa $(58,4 \%)$ yang bersikap mendukung perilaku merokok.

3. Dari 77 orang siswa di MTS Negeri 01 Kota Lubuklinggau, terdapat 43 orang siswa $(55,8 \%)$ yang memiliki teman sebaya yang mendukung perilaku merokok.

4. Dari 77 orang siswa di MTS Negeri 01 Kota Lubuklinggau, terdapat 46 orang siswa $(59,7 \%)$ yang memiliki perilaku merokok.

5. Ada hubungan antara pengetahuan siswa dengan perilaku merokok pada siswa di MTS Negeri 01 Kota Lubuklinggau dengan kategori hubungan sedang.

6. Ada hubungan antara sikap siswa dengan perilaku merokok pada siswa di MTS Negeri 01 Kota Lubuklinggau dengan kategori hubungan sedang.

7. Ada hubungan antara teman sebaya dengan perilaku merokok pada siswa di 
MTS Negeri 01 Kota Lubuklinggau dengan kategori hubungan sedang.

\section{DAFTAR PUSTAKA}

Hasanah, A. U., dan Sulastri. (2011). Hubungan antara Dukungan Orang Tua, Teman Sebaya dan Iklan Rokok dengan Perilaku Merokok pada Siswa Laki-Laki Madrasah Aliyah Negeri 2 Boyolali, GASTER, 8 (1), pp. 695-705. Diunduh dari

https://www.jurnal.stikesaisyiyah.ac.id/index.php/gaster/article/ view/22/19.

Kemenkes RI. (2018). WHO : Merokok Sebabkan Jutaan Kasus Serangan Jantung. Diunduh dari : http://www.p2ptm.kemkes.go.id/artikel -penyakit/who-merokok-sebabkanjutaan-kasus-serangan-jantung.

Kemenkes RI. (2013). Riset Kesehatan Dasar (Riskesdas) 2013. Jakarta : Kemenkes RI.

Komasari, D. dan Helmi, A. F. (2000). Faktor-Faktor Penyebab Perilaku Merokok pada Remaja, Jurnal Psikologi, 27 (1), pp. 37-47. Diunduh dari : jurnal.ugm.ac.id > jpsi > article > view.

Kurniasih, A. (2008). Faktor-Faktor yang Berhubungan dengan Perilaku Merokok pada Siswa SMP Kota Bekasi Tahun 2008. Skripsi. Depok : Fakultas Kesehatan Masyarakat Universitas Indonesia.
Maseda, D. R., Suba, B., dan Wongkar, D. (2013). Hubungan Pengetahuan dan Sikap tentang Bahaya Merokok dengan Perilaku Merokok pada Remaja Putra di SMA Negeri I Tompasobaru, Ejournal Keperawatan (e-Kp), 1 (1).

Diunduh dari https://media.neliti.com/media/publicat ions/108638-ID-none.pdf.

Notoatmodjo, S. (2014). Ilmu Perilaku Kesehatan. Jakarta: Rineka Cipta.

Notoatmodjo, S. (2010). Promosi Kesehatan Teori dan Aplikasi. Jakarta: Rineka Cipta.

Pangestu, A. W., Cahyo K., dan Kusumawati A. (2017). Faktor-Faktor Yang Berhubungan dengan Perilaku Merokok Shisha pada Siswa SMA X di Kota Semarang, Jurnal Kesehatan Masyarakat, 5 (1), pp. 489-498. Diunduh dari

https://ejournal3.undip.ac.id/index.php/ $\mathrm{jkm} /$ article/view/15829/15301.

Santrock, J. W. (2003). Life Span Development, Perkembangan Masa Hidup. Jakarta: Erlangga.

Suprayitno. A. (2013). Pengaruh Teman Sebaya Terhadap Perilaku Merokok Remaja di SMK Sepuluh November Semarang Tahun 2013. Skripsi. FIKK Universitas Muhammadiyah Semarang. Diunduh dari : https://adoc.tips/pengaruh-temansebaya-terhadap-perilaku-merokokremaja-di-sm.html. 